\title{
Effect of Different Sugar Solutions, Temperature and Relative Humidity on Uredospore Germination of Cerotelium fici (Cast.) Arth. Causing Rust Disease on Fig (Ficus carica Linn.)
}

\author{
A. Anusha ${ }^{1 *}$, Y. S. Mahesh ${ }^{1}$, R. K. Mesta ${ }^{1}$, M. P. Basavarajappa ${ }^{1}$, \\ S. N. Patil ${ }^{2}$ and A. G. Babu ${ }^{3}$ \\ ${ }^{1}$ Department of Plant Pathology, University of Horticultural Sciences, Bagalkot- 587104, \\ Karnataka, India \\ ${ }^{2}$ Department of Fruit Science, KRC College of Horticulture, Arabhavi- 591218, \\ Karnataka, India \\ ${ }^{3}$ Directorate of Research, UHS, Bagalkot- 587104, Karnataka, India \\ *Corresponding author
}

\section{A B S T R A C T}

\section{Keywords}

Fig (Ficus carica L.), Blastophaga psenes, Cerotelium fici

Article Info

Accepted:

26 October 2018

Available Online:

10 November 2018
Fig rust caused by Cerotelium fici is one of the most important fungal diseases on Ficus carica responsible for about 50 per cent losses both in terms of yield and quality of the produce. The fungal spore germination is affected by the nutrient availability and environmental factors like temperature and relative humidity. Therefore, an experiment was conducted with respect to the uredospore germination of $C$. fici at different concentrations of sugars, temperature and relative humidity. The results revealed that the uredospores germinated at maximum rate in water agar containing 2.5 per sucrose $(51.79 \%)$ and least in RO water $(4.22 \%)$. The optimum temperature for uredospore germination found was $25^{\circ} \mathrm{C}$ after $24 \mathrm{hrs}$ of incubation at which the maximum germination $(51.10 \%)$ was observed. Relative humidity has showed maximum influence on the uredospore germination with highest germination per cent $(60.38 \%)$ at 100 per cent relative humidity and no germination was observed at 65 per cent relative humidity.

\section{Introduction}

Fig (Ficus carica L.) is an important deciduous fruit crop of tropical and subtropical countries. It belongs to the family, Moraceae. Edible fig is known for its fruits and has been cultivated for thousands of years. The latin name, carica comes from the location Caria in Asia Minor which is supposedly the home of the fig (Starr et al., 2003). The pollination of fig is very special and reflects symbiotic relationships. It is carried out by a parasitic species-specific wasp (Blastophaga psenes) whose life-cycle is synchronized with that of the tree.

Figs are highly nutritious rich in calories. The protein and calcium content in fig fruit is higher than that of the milk. It has nutritive index of 11, as against 9, 8 and 6 for apple, raisin and date respectively. Therefore, the fig has secured a significant place in the world. 
The total land brought under the cultivation of fig in the world is 4.15 lakh ha. Turkey is the leading fig producing country in the world, followed by Egypt and Algeria.

In India, total area under fig cultivation is 13,802 ha with the production of 24,646 tons, mostly with an average productivity of 2,516 $\mathrm{kg} / \mathrm{ha}$ during the year 2014-15 (FAO, 2017). India ranks fifteenth in fig production in the world. However in case of productivity, India ranks twenty second. Its cultivation is mostly confined to western part of Maharashtra, Gujarat, Uttar Pradesh (Lucknow and Saharanpur), Karnataka (Bellary, Chitradurga and Koppal) and Tamil Nadu (Chadha, 2001). Karnataka stands next to Maharashtra in fig cultivation holding an area of about 641 ha, producing an average of 6,021 metric tons of fig fruits annually with highest productivity of 9.39 tons/ ha/ year (Anon., 2017).

The fig production is constrained by many factors major being the rust disease caused by Ceotelium fici. The genus is closely related to Phakopsora parasitizing leguminous crops (ono et al., 1992). The symptoms of the disease appear initially as tiny yellow spots on underside of the leaves. They enlarge to form reddish brown angular spots visible on lower and upper leaf surfaces. Leaves are the severely affected plant part by rust disease.

However, under congenial condition, symptoms also appear on petiole, shoots and fruits. Severe disease incidence results in leaf drying and defoliation. About 50 per cent losses have been reported by earlier workers (Gaikwad and Nimbalkar, 2004), indicating the seriousness of rust disease in fig.

For the biotrophic parasites, determination of the in vitro sensitivity of a fungus to a fungicide requires the identification of different factors such as substrate (Sugars), a particular environment like temperature and relative humidity, which promotes the highest rate of spore germination in the shortest time.

The aim of this study was to select substrate, temperature and relative humidity for promoting maximum germination of $C$. fici uredospores.

\section{Materials and Methods}

In vitro experiments were conducted at Department of Plant Pathology, College of Horticlture, Bagalkot, UHS, Bagalkot during 2017-2018. The C. fici uredospores sample was collected from naturally infected plants in the Fruit orchard, UHS, Bagalkot, during morning hours.

\section{Effects of sugar on uredospore germination}

The germination of uredospores was studied in tap water, RO water, distilled water and the water agar $(0.5 \%)$ containing sucrose $(0.5,1.0$, $1.5,2.0,2.5$ and $3.0 \%)$ and dextrose $(0.5,1.0$, $1.5,2.0,2.5$ and $3.0 \%$ ) using cavity slide method.

Spores from the leaf surface transferred to the eppendorf tubes to which the respective media added and vortexed to get the spores finely distributed in the media. Later $200 \mu$ l of suspension was transferred to the cavity slides. The ambient temperature of $25^{\circ} \mathrm{C}$ and 85 per cent $\mathrm{RH}$ was maintained throughout the experiment. The observations recorded after 24 hours by counting number of spores germinated per microscopic field (10 X magnification) and four microscopic fields were counted. The spores producing the germtube twice their size was considered as germinated. The per cent germination was calculated by using the formula,

No of uredospores germinated Per cent spore germination = ------------- x 100 Total no of uredospores observed 
Effect of temperature on uredospore germination

The cardinal temperature required for spore germination was carried out using cavity slide method. Uredospore suspension prepared in water agar ( $0.5 \%$ agar) containing 2.5 per cent sucrose. The cavity slides were kept in the petriplates lined with the moistened blotting paper incubated at temperature ranging from 10 to $40{ }^{\circ} \mathrm{C}$ in an incubator for $24 \mathrm{~h}$. Three replications were maintained for each temperature and the observations were recorded after $24 \mathrm{~h}$. The per cent spore germination was calculated and analysed statistically.

\section{Effect of relative humidity (RH) on uredospore germination}

Two hundred $\mu$ of spore suspension prepared in water agar containing 2.5 per cent sucrose solution was taken on a cavity slide. The cavity slides were incubated at $25^{\circ} \mathrm{C}$ by maintaining different relative humidity levels viz., $60,65,70,75,80,85,90$ and 95 per cent by dissolving $38,36,33,30,27,23,18$ and 11 per cent concentrated sulphuric acid $\left(\mathrm{H}_{2} \mathrm{SO}_{4}\right)$ respectively in the desiccators containing distilled water. 100 per cent RH was obtained by adding no sulphuric acid to the distilled water in a desiccator (Solomon, 1951). Three replications were maintained for each treatment. Uredospore germination was observed after $24 \mathrm{~h}$ of incubation and the per cent germination was calculated.

\section{Results and Discussion}

\section{Effect of sugars on uredospore germination}

The results presented in the Table 1 and fig. 1 revealed that the least spore germination was observed in RO water (4.22\%), which was on par with distilled water $(4.29 \%)$ and tap water $(4.56 \%)$. The sucrose at 2.5 per cent concentration recorded the maximum uredospore germination (51.79\%) and was found to be significantly superior than the other concentrations tested. The sucrose at 2.0 per cent was found as next best treatment showing 43.41 per cent spore germination, which was followed by dextrose at 2.0 per cent concentration $(43.05 \%)$ and sucrose at 3.0 per cent $(42.23 \%)$. Among the sugar concentrations tested, the dextrose at 3.0 per cent has recorded the least germination (24.18\%) followed by sucrose at 0.5 percent $(27.00 \%)$ and dextrose at 0.5 per cent concentration $(28.86 \%)$ and these were found to be significantly different from each other.

\section{Effect of temperature on uredospore germination}

The studies on uredospore germination was conducted at different temperatures from 10 to $40{ }^{\circ} \mathrm{C}$. From the data indicated in Table 2 and fig. 2 , it is clear that mean maximum spore germination was observed at $25^{\circ} \mathrm{C}$ and was significantly superior over $20^{\circ} \mathrm{C}(37.34 \%)$ and $15^{\circ} \mathrm{C}(14.45 \%)$ temperature. Amongst all the treatments, least per cent uredospore germination was recorded at $40{ }^{\circ} \mathrm{C}(1.22 \%)$.

\section{Effect of relative humidity on uredospore germination}

The data on the uredospore germination at different RH (\%) tested is presented in the Table 3 and Fig. 3, which clearly showed that the mean maximum uredospore germination was at 100 per cent RH (60.38\%) followed by 95 per cent $(49.56 \%)$. The least spore germination was recorded at 70 per cent $\mathrm{RH}$ (3.54\%). At 65 per cent $\mathrm{RH}$, uredospore germination was not observed.

Survival and rapid germination of uredospores is an important factor in causing rapid infection to host tissues and thus assuring perpetuation (Sunkad and Kulkarni, 2007) 
which is influenced by the availability of host and environmental factors. Therefore the present research finding is also helpful for understanding the fig rust disease development.

\section{Effect of sugars on uredospore germination}

Spore germination is an essential developmental stage in the life cycle of fungi, which involves the conversion of resting or dormant spore into a rapidly growing germtube from which the mycelium will be produced and the nutrients must be taken up by the spore to initiate, and to maintain the progress of germination. The constituents of substrate are known to influence spore germination of fungi.

The maximum spore germination was observed in water agar with 2.5 per cent sucrose followed by 2.0 per cent sucrose and 2 per cent dextrose and least spore germination in RO water as compared to distilled water and tap water. The reduced germination in the tap water, distilled water and RO water was due to the lack of nutrients. Water agar is the most used substrate for fungal spore germination studies. Kochman and Brown (2008) observed higher rates of spore germination for Puccinia graminis avenae Erikss. \& Henn. and Puccinia coronata avenae Fraser \& Led. by using the substrate water-agar in vitro, compared to germination on oat leaves.

Our research findings are in comparsions with Sumangala et al., (2014). They found that, the uredospore germination of brown rust pathogen of sugar cane was maximum in sucrose at 2.0 per cent and least in 0.5 per cent sucrose. The uresodospore germination per cent depletes with the decreasing nutrient availability. Here in the present research beyond 2.5 per cent sucrose the germination per cent decreased showing that the optimum concentration of sugars is more appropriate for enhancing the uredospore germination per.

Blum et al., (2015) found the highest germination and germ tube length of Phakopsora pachyrhizi in soybean leaf eaxtract agar comapared to water agar which shows that host perceptions stimulates the uredospore germination.

\section{Effect of temperature on uredospore germination}

Temperature plays an important role among the physical factors, which influences distribution, growth and reproduction of the fungus. As a part of the research programme, we determined temperature effects on uredospore germination. The present study has clearly showed that temperature from 15 to $25^{\circ} \mathrm{C}$ promotes the spore germination and $25^{\circ}$ $\mathrm{C}$ is optimum to initiate the uredospore germination and beyond which the germination decreased gradually.

Doodley (1984) reported that, uredospores were killed when exposed to $30^{\circ} \mathrm{C}$ for six $\mathrm{hr}$ and at $35^{\circ} \mathrm{C}$ for $30 \mathrm{~min}$, which might be one of reason for decrease in uredospore germination with the increasing temperature above $25^{\circ} \mathrm{C}$.

These findings are in agreement with Blum et al., (2015) who has reported that the optimal temperature estimated for $P$. pachyrhizi spore germination was $21.8^{\circ} \mathrm{C}$ and $22.3^{\circ} \mathrm{C}$ in continuous darkness for six hours. Bonde et al., (2007) evaluated different isolates and obtained the maximum spore germination in the temperature range between 21.8 and $23.4^{\circ}$ $\mathrm{C}$, while for germ tube growth the range was between 21.0 and $24.4^{\circ} \mathrm{C}$. And also reported that temperature affected spore germination and germ tube growth in the same manner and degree as it affected initial disease development. 
Table.1 Standardization of different concentrations of sugar solution on uredospore germination of Cerotelium fici

\begin{tabular}{|c|l|c|}
\hline SI. No. & \multicolumn{1}{|c|}{ Media } & Sugar conc. (\%) \\
\hline 1 & Tap Water & -- \\
\hline 2 & RO water & -- \\
\hline 3 & Distilled water & -- \\
\hline 4 & Sucrose & 0.5 \\
\hline 5 & Sucrose & 1.0 \\
\hline 6 & Sucrose & 1.5 \\
\hline 7 & Sucrose & 2.0 \\
\hline $\mathbf{8}$ & Sucrose & 2.5 \\
\hline 9 & Sucrose & 3.0 \\
\hline 10 & Dextrose & 0.5 \\
\hline 11 & Dextrose & 1.0 \\
\hline 12 & Dextrose & 1.5 \\
\hline 13 & Dextrose & 2.0 \\
\hline 14 & Dextrose & 2.5 \\
\hline 15 & Dextrose & 3.0 \\
\hline & & \\
\hline
\end{tabular}

\begin{tabular}{|c|}
\hline Spore germination $(\%)$ \\
\hline $4.56(12.33)$ \\
\hline $4.22(11.86)$ \\
\hline $4.29(11.95)$ \\
\hline $27(31.30)$ \\
\hline $33.98(35.66)$ \\
\hline $38.3(38.23)$ \\
\hline $43.41(41.21)$ \\
\hline $51.79(46.03)$ \\
\hline $42.23(40.59)$ \\
\hline $28.86(32.49)$ \\
\hline $31.94(34.41)$ \\
\hline $35.34(36.48)$ \\
\hline $43.05(41.01)$ \\
\hline $39.16(38.74)$ \\
\hline $24.18(29.45)$ \\
\hline 0.31 \\
\hline 0.90
\end{tabular}

*Values in the parenthesis are arc sine transformed

Table.2 Effect of temperature on uredospore germination of Cerotelium fici

\begin{tabular}{|c|c|c|}
\hline Sl. No. & Temperature $\left({ }^{\circ} \mathrm{C}\right)$ & Spore germination (\%) \\
\hline 1 & 10 & $8.48(16.19)$ \\
\hline 2 & 15 & $14.45(22.32)$ \\
\hline 3 & 20 & $37.34(37.65)$ \\
\hline 4 & 25 & $51.10(45.61)$ \\
\hline 5 & 30 & $8.27(16.70)$ \\
\hline 6 & 35 & $6.71(14.95)$ \\
\hline \multirow[t]{3}{*}{7} & 40 & $1.22(6.10)$ \\
\hline & S. Em \pm & 0.72 \\
\hline & CD@0.01 & 2.21 \\
\hline
\end{tabular}

*Values in the paranthesis are arc sine transformed

Table.3 Effect of relative humidity on uredospore germination of Cerotelium fici

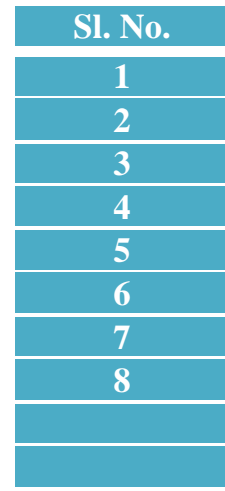

\begin{tabular}{|r|}
\hline Relative humidity (\%) \\
\hline 65 \\
\hline 70 \\
\hline 75 \\
\hline 80 \\
\hline 85 \\
\hline 90 \\
\hline 95 \\
\hline 100 \\
\hline \\
\hline \\
\hline
\end{tabular}

\begin{tabular}{|c|}
\hline Spore germination $(\%)$ \\
\hline $0.00(5.73)$ \\
\hline $3.54(10.83)$ \\
\hline $6.00(14.13)$ \\
\hline $10.16(18.56)$ \\
\hline $22.54(28.32)$ \\
\hline $24.17(29.42)$ \\
\hline $49.56(44.73)$ \\
\hline $60.38(50.96)$ \\
\hline 0.47 \\
\hline 1.38 \\
\hline
\end{tabular}

*Values in the paranthesis are arc sine transformed 

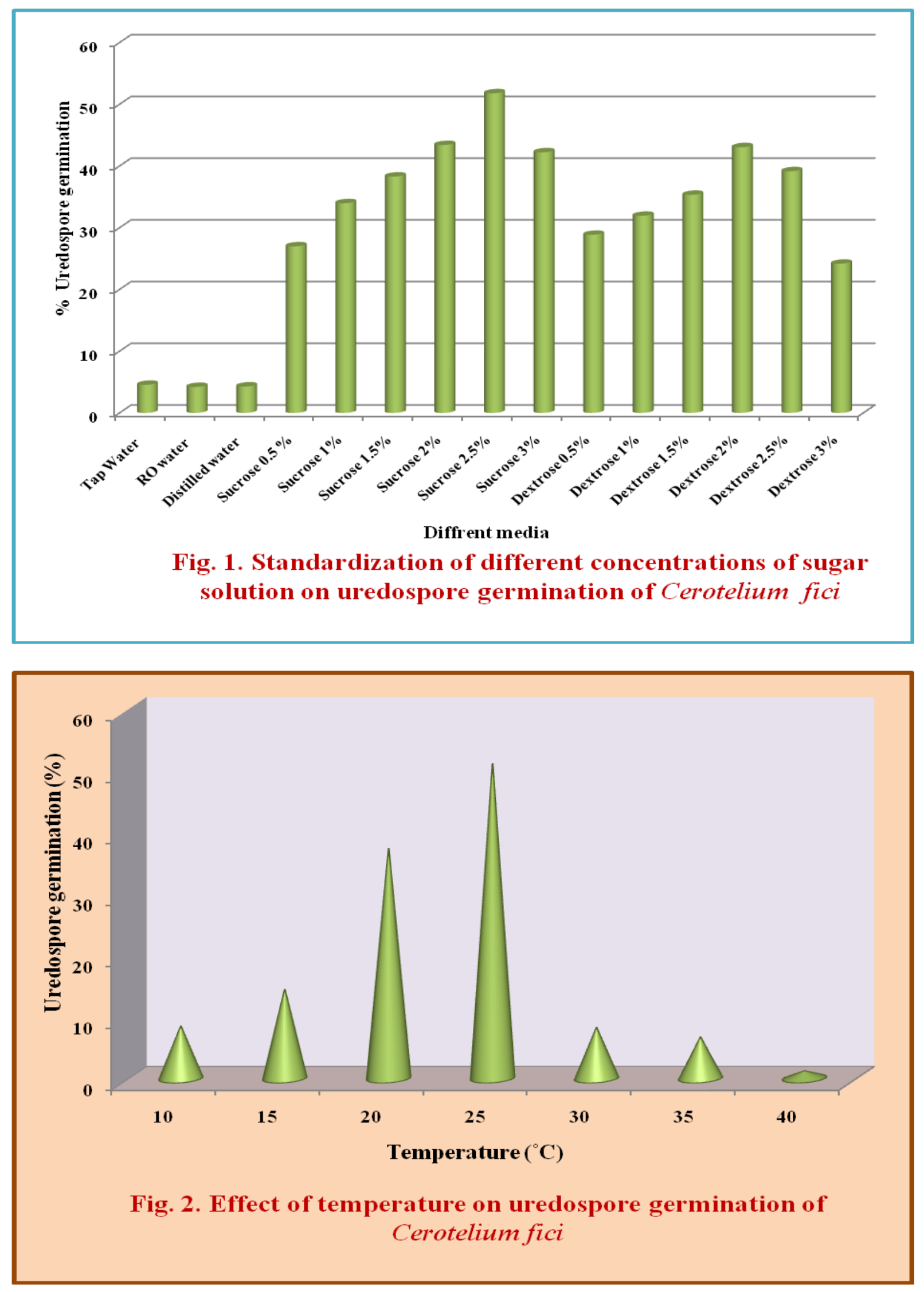


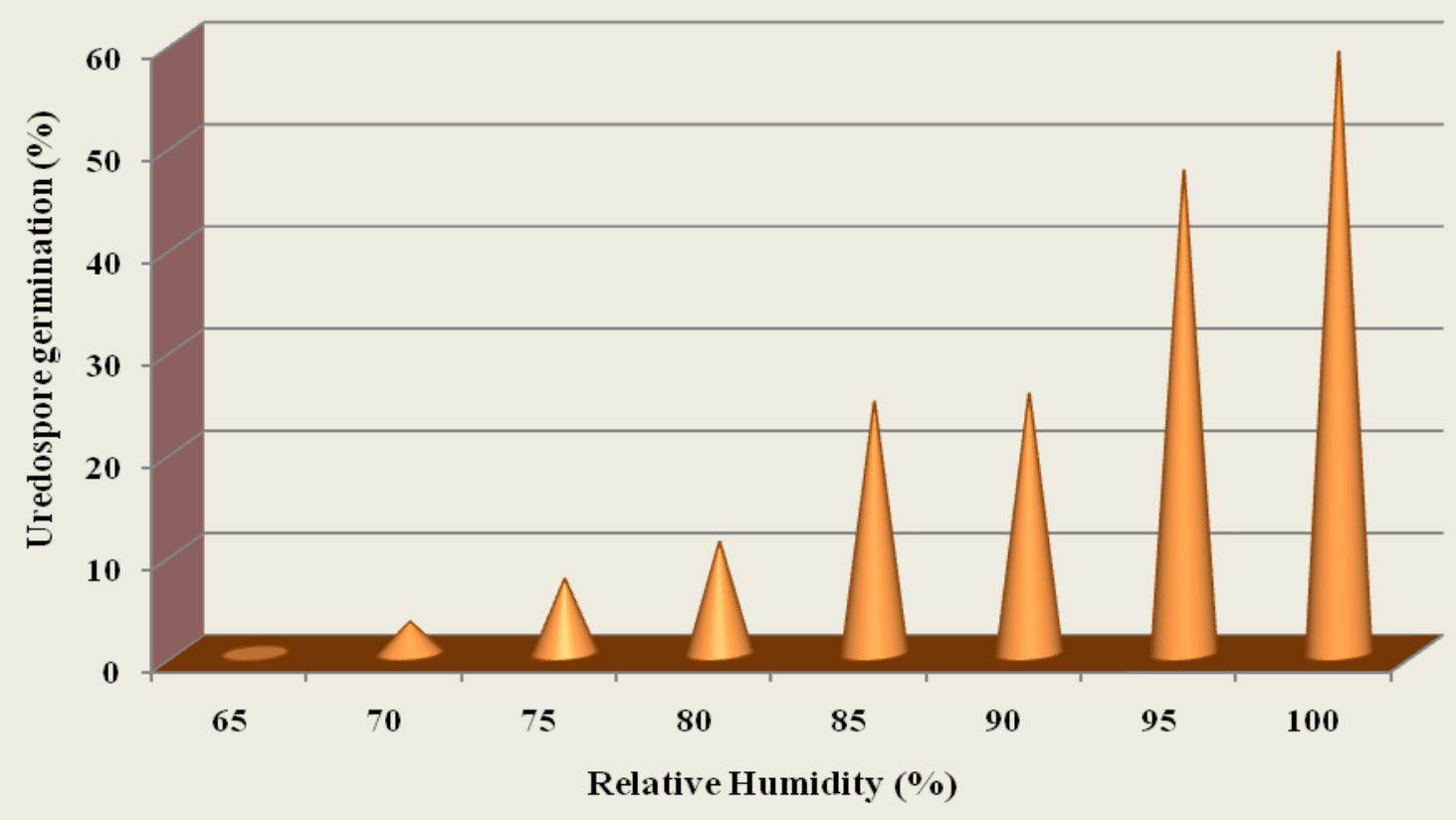

Fig. 3. Effect of relative humidity on uredospore germination of Cerotelium fici

Sumangala et al., (2014) evaluated the optimum temperature for uredospore germination of Puccinia melanocephala and reported that uredospore germinate at temperature range of $5^{\circ} \mathrm{C}$ to $35^{\circ} \mathrm{C}$.

Our research findings are also cordial with Veena and Adiver (2015) and Dey et al., (2015) who has reported the maximum uredospore germination per cent at $25^{\circ} \mathrm{C}$.

\section{Effect of relative humidity on uredospore germination}

Relative humidity markedly affected the $C$. fici uredospore germination. In the present investigation, the maximum uredospore germination was observed at 100 per cent RH followed by 95 per cent and at 65 per cent no germination was reported. The results are in conformity with the results of Doodley (1984) who has observed the uredial development of Melampsoridium betulinum on the detached leaf at 100 per cent relative humidity. Veena and Adiver (2015) reported the highest uredospore germination of Puccinia arachadis at 90 per cent $\mathrm{RH}$ and least at 65 per cent. Whereas, Sumangala et al., (2015) reported the maximum uredospore germination of $P$. melanocephala at 85 per cent RH. The uredospore germination was decreased with decreasing humidity which concludes that the rust disease is favoured by humid weather.

\section{Acknowledgement}

Sincere thanks to the faculties of Department of Plant Pathology, College of Horticulture, Bagalkot and to all the researchers whose work was immensely helpful to carry out the research. 


\section{References}

Anonymous, 2017, Agriculture Department of Maharashtra (2009-10), Pune.

Blum, M. M. C., Reis, E. M., Franciei, T. V. and Carlini, R., 2015. In vitro effect of substrate, temperature and photoperiod on Phakopsora pachyrhizi urediniospore germination and germ tube growth. Summa Phytopathologica. 4(2): 101-106.

Bonde, M. R., Berner, D. K., Nester, S. E. and Frederick R. D. 2007. Effects of temperature on urediniospore germination, germ tube growth, and initiation of infection in soybean by Phakopsora isolates. Phytopathology. 97(8): 997-1003.

Chadha, K. L. 2001. Handbook of Horticulture. Indian Council of Agricultural Research, New Delhi. pp. 176.

Dey, U., Harlapur, S. I., Dhutraj, D. N. and Pawar, D.V. 2015. Effect of different temperature levels and time intervals on germination of uredospores of Puccinia sorghi. Afr. J. Microbiol. Res. 9(19): 1299-1303.

Doodley, H. L. 1984. Temperature effects on germination of uredospores of Melampsoridium betulinum and on rust development. Plant Disease. 68(8): 686-688.

FAO. 2017. Agriculture data. FAO stat agriculture, Aug. 2017.

Gaikwad, A. P. and Nimbalkar, C. A. 2004. Management of fig rust with fungicides. J. Mycol. Pl. Pathol. 39(2): 418-419.
Kochman, J. K. and Brown, J. F. 2008. Effect of temperature, light and host on prepenetration development of Puccinia graminis avenae and Puccinia coronata avenae. Ann. App. Biol. 82: 241-249.

Ono, Y., Buritica, P. and Hennen, J. F., 1992. Delimitation of Phakopsora, Physopella and Cerotelium and their species on Leguminosae. Mycological Research. 96(10): 825-850.

Solomon, M. E. 1951. Control of humidity with potassium hydroxide, sulphuric acid or other solutions. Bulletin Entomol. Res. 42: 543-554.

Starr, F., Starr, K. and Loope, L., 2003, Ficus carica: Edible fig, Moraceae. Maui, Hawaii, United States Geological Survey-Biological Resources Division, Haleakala Field Station.

Sumangala E. Nalwar, Hundekar A. R. and Vinamrta G. Patil Kulkarni. 2014. Effect of temperature, relative humidity and different sugar solution on uredospore germination of sugarcane rust caused by Puccinia melanocephala $\mathrm{H}$ and P. Syd. Trends in Biosciences. 7(12): 1310-1313.

Sunkad, G and Kulkarni, S. Studies on Perpetuation and Carry over of Groundnut Rust (Puccinia arachidis Speg.) in Northern Karnataka. Karnataka J. Agric. Sci. 20(2): 297-300.

Veena and Adiver, S. S., 2015. Effect of physiological factors on uredospores of different isolates of Puccinia archadis Speg. causing rust disease in groundnut. Trends in Biosciences. 8(13): 33783384.

\section{How to cite this article:}

Anusha A., Y. S. Mahesh, R. K. Mesta, M. P. Basavarajappa, S. N. Patil and Babu A. G. 2018. Effect of Different Sugar Solutions, Temperature and Relative Humidity on Uredospore Germination of Cerotelium fici (Cast.) Arth. Causing Rust Disease on Fig (Ficus carica Linn.). Int.J.Curr.Microbiol.App.Sci. 7(11): 3558-3565. doi: https://doi.org/10.20546/ijcmas.2018.711.408 